\title{
Intuicja matematyczna w ujęciu nowoczesnego racjonalizmu
}

\author{
Witold Marciszewski \\ (Politechnika Warszawska, Międzynarodowe Centrum Ontologii Formalnej)
}

\section{Ad Lectorem Benevolentem}

Każdy kierunek filozoficzny w swoim trwaniu i rozwoju przez stulecia czy tysiąclecia, przechodzi przez różnorodne fazy rozwojowe. Śledząc dzieje myśli, widzimy, jak podlegały temu prawu: empiryzm, sceptycyzm, nominalizm, pozytywizm i niemało innych „izmów”. Trudno więc, by to nie dotyczyło dziejów racjonalizmu, jako kierunku, który w epistemologii jest adwersarzem empiryzmu, a w ontologii - nominalizmu.

Proces takich transformacji $\mathrm{w}$ racjonalizmie można opisywać $\mathrm{w}$ podobny sposób jak w przypadku innych doniosłych nurtów myśli. Jednak zamysł tego opracowania jest śmielszy. Twierdzę, że racjonalizm jest wart szczególnej uwagi, gdy chodzi o głębię i doniosłość transformacji, jaka się w nim dokonała w XX stuleciu. Tej jego osobliwości poświęcam obecne rozważania. Ponieważ temat jest nader rozległy, to pomijając wiele spraw, skupię się na jednej z nich: kwestii intuicji intelektualnej, a w szczególności matematycznej. Jest to bowiem materia, która przyciąga uwagę wielu wybitnych umysłów, od których wiele się można nauczyć (zob. uwagi J. Pogonowskiego o intuicji matematycznejp).

Posłużenie się terminem „racjonalizm nowoczesny” lub krócej „neoracjonalizm” jest dość ryzykowną innowacją terminologiczną. Choćby dlatego, że żaden

1 J. Pogonowski, Kilka uwag o intuicji matematycznej, „Filozofia Nauki” 2012, nr 2(78). 
z autorów, na których się powołuję, nie określa siebie mianem „neoracjonalisty”. $Z$ reguły stosuje się umownie określenie „platonizm”. Od historycznego Platona jest ono jednak odległe, choćby dlatego, że nie da się doń zastosować przypowieści o jaskini, tak istotnej dla platońskiej epistemologii. Inaczej ma się rzecz z ontologią, gdzie istotnie zachodzi pewna analogia, gdy pojąć platonizm jako tzw. realizm matematyczny - tak jak definiuje go Gödel w słynnym odczycie Gibbsa. Pogląd ten przedstawiono następująco:

Mathematical objects and concepts form an objective reality of their own, which we cannot create or change, but only perceive and describe ${ }^{2}$.

To zdanie oddaje jedną część Gödlowskiej filozofii matematyki, mianowicie część ontologiczną. Nie ma tu jednak analogii z Platonem w części epistemologicznej. Mamy zaś do czynienia z tendencją - którą podzielali z Gödlem Tarski, Quine i inni - do upatrywania podobieństw metodologicznych między matematyką i naukami empirycznymi. Stąd nasuwa się potrzeba innego niż „platonizm” określenia dla tej klasy poglądów.

Jeszcze inne ryzyko terminologiczne wiąże się z tym, że istnieją autorzy anglo- i niemieckojęzyczni używający terminów „neo-rationalism” lub „Neorationalismus” w znaczeniu zbliżonym do mojej propozycji, gdy poruszają temat intuicji intelektualnej; czynią to jednak w innym kontekście niż tu prezentowany. Dla neoracjonalizmu w proponowanym tu rozumieniu charakterystyczny jest matematyczny realizm oraz powiązanie z ideami Gödla i Turinga, na których się skupiają obecne rozważania ${ }^{3}$.

Proponowana tutaj strategia terminologiczna powinna też pomóc w prostowaniu takich niedokładności jak np. ta zaistniała w artykule Rationalism w anglojęzycznej wersji Wikipedii, zgodnie z którą nowoczesny (modern) racjonalizm datuje się od Kartezjusza. Racjonalizm Kartezjusza i innych klasyków XVII wie-

Zob. G. Boolos, Logic, Logic, and Logic, Harvard University Press, Cambridge, MA 1999, s. 106. Gödla dotyczy, w szczególności \$3. Co się tyczy Turinga [1939], to wchodzi w grę jego podejście do kwestii intuicji matematycznej w terminach „wyroczni” (oracle), zdolnej znajdować wartości funkcji nieobliczalnych. Omawianie tego wyrafinowanego pomysłu zwiększyłoby niepomiernie objętość obecnego tekstu. Toteż odsyłam w tej kwestii do stosunkowo niedawnych publikacji naświetlających tę kwestię: W. Marciszewski, Does Science Progress towards Ever Higher Solvability through Feedbacks between Insights and Routines?, „Studia Semiotyczne” 2018, t. XXXII, nr 2, s. 153-185; W. Marciszewski, The Progress of Science from a Computational Point of View: the Drive towards Ever Higher Solvability, „Foundations of Computing and Decision Sciences” 2019, Vol. 44, Issue 1, s. 11-26. 
ku był nowoczesny w stosunku do Platona czy stoików, jednak nie mógł uwzględniać przełomowych dla epistemologii wyników nowoczesnej logiki XIX i XX wieku, toteż datowanie racjonalizmu od Kartezjusza nie ma tu racji bytu.

Neoracjonalizm podziela do pewnego stopnia rozmach i maksymalizm poznawczy racjonalizmu klasycznego, którego filarami byli Kartezjusz i Leibniz ${ }^{4}$. W pewnych jednak istotnych sprawach tak dalece jest on odmienny od swego czcigodnego antenata, że zasługuje na własne imię.

Istotną różnicę stanowi pojmowanie intuicji intelektualnej, w szczególności matematycznej. Pojęcie to nie ma już dziś zakorzenienia w metafizycznej koncepcji umysłu, która w różnych wariantach, lecz podobnych co do istoty, była żywa w czasach Platona, Augustyna i scholastyki, a potem w złotym wieku racjonalizmu, jakim było stulecie klasyków - wiek XVII. Od Augustyna po Leibniza koncepcja wiedzy apriorycznej, osiąganej przez intuicję intelektualną, była integralnie spojona z teologiczną ideą Stwórcy darzącego umysł „światłem naturalnym" (jak to ujmował Kartezjusz). Sekularyzacja myślenia, prąd tak wiele znaczący w ewolucji kulturowej trzech minionych wieków, o czym trafnie pisze Bartoś, snując uwagi o sekularyzmie ${ }^{5}$, który pozbawił racjonalizm tak istotnej dlań kiedyś legitymizacji.

Jeszcze głębsze zmiany przyniosła rewolucja naukowa w logice, zainicjowana przez Boole'a i Fregego, eksplodująca w kolejnych fazach osiągnięciami Hilberta, Tarskiego, Gödla, Turinga. Z tych nowych korzeni wyrosła nowoczesna koncepcja racjonalizmu. To drugi argument za „neo-”.

Znaczącym wyróżnikiem nowej koncepcji jest też okoliczność, że totalny optymizm poznawczy klasyków racjonalizmu zamienił się w postawę, która też jest optymistyczna, lecz z większym realizmem co do granic możliwości poznawczych. Ów realizm bierze się z fundamentalnych odkryć w metamatematyce. Był to Gödla ${ }^{6}$ dowód niezupełności teorii liczb oraz Turinga ${ }^{7}$ i (niezależnie w 1936 r.) Churcha dowód nierozstrzygalności logiki predykatów.

$4 \quad$ Ich charakterystyki w szerokim kontekście historycznym można znaleźć w książkach: W. Marciszewski, Logic from a Rhetorical Point of View, de Gruyter, Berlin 1994; W. Marciszewski, R. Murawski, Mechanization of Reasoning in a Historical Perspective, Rodopi, Amsterdam 1995.

5 T. Bartoś, Hypermodernizm, czyli co zrobić, by tworzenie nowych pojęć nie poszerzało naszej wie$d z y$, „Edukacja Filozoficzna” 2018, nr 66, s. 187.

6 Zob. K. Gödel, Über formal unentscheidbare Sätze der Principia mathematica und verwandter Systeme I, „Monatshefte für Mathematik und Physik” 1931, nr 38, s. 173-198.

7 Zob. A. Turing, On Computable Numbers, with an Application to the Entscheidungsproblem, „Proceedings of the London Mathematical Society” 1937, Vol. s2-42, Issue 1, s. 230-265. 
I jeszcze jedna nowość: wyrazista dotychczas opozycja racjonalizm kontra empiryzm staje się bardziej stonowana, gdy zauważy się rolę doświadczenia zmysłowego w genezie intuicji matematycznej. Nowi racjonaliści, w tym Kurt Gödel, dostrzegli udział spostrzeżeń zmysłowych u źródła procesów poznawczych, w których kształtują się intuicyjne pojęcia zbioru i liczby na najniższym, wyjściowym, poziomie abstrakcji.

Zaczynając te rozważania apelem do czytelnika życzliwego, zwyczajem poniektórych dawnych autorów, liczę na jego cierpliwość w śledzeniu dość niuansowych rozróżnień. Terminem „nowoczesny racjonalizm” obejmuję mocno zróżnicowaną grupę czołowych filozofów matematyki XX wieku, trzeba więc ogarniać jednym jakby spojrzeniem, co ich łączy i co różni. W tym spektrum znajdą się Frege, Russell, Church, Bernays, Gödel, Quine, Putnam, Kreisel, Chaitin, Ajdukiewicz, a w pewnym sensie także Tarski, i pokaźny poczet innych nazwisk ${ }^{8}$.

Tarski, na przykład, nigdzie się nie deklarował jako platonik (raczej jako materialista i nominalista), ale był nim w praktyce jako autor wysoce abstrakcyjnej teorii mnogości, gdzie mówi się np. o istnieniu nieosiągalnych (inaccessible) liczb kardynalnych, których nie wymyślamy, lecz o których się dowiadujemy - co spełnia Gödlowską definicję platonizmu. Trzeba więc, myśląc o takich przypadkach, pamiętać też o rozbieżności deklaracji i praktyki.

Wymaga też pewnej finezji porównywanie stanowisk Gödla i Quine'a. Przekonująco czyni to Wójtowicz ${ }^{9}$, ukazując podobieństwa, ale też istotne dla Quine’a punkty, rodzące wątpliwość, czy słuszne jest lokować go w poczcie racjonalistów. Trzeba więc mieć pewną odporność na takie wątpliwości i cierpliwość w operowaniu niuansami, stąd apel do życzliwego czytelnika o wyrozumiałe znoszenie dolegliwości natury definicyjnej.

8 Zob.: Y. Gurevich, Platonism, Constructivism, and Computer Proofs vs. Proofs by Hand, w: Current Trendsi $n$ Theoretical Computer Science. Entering the 21st Century, eds. M. Nielsen, G. Paun, G. Rozenberg, A. Salomaa, World Scientific, Washington, D.C. 2001; V. Rodych, Are Platonism and Pragmatism Compatible?, w: Mistakes of Reason: Essays in Honour of John Woods, ed. J.H. Woods, University of Toronto Press 2005; R. Tieszen, Gödel and Quine on Meaning and Mathematics, w: Between Logic and Intuition. Essays in Honor of Charles Parsons, eds. G. Sherman, R. Tieszen, Cambridge University Press, Cambridge 2000.

9 K. Wójtowicz, Platonizm matematyczny. Studium filozofii matematyki Kurta Gödla, OBI, Biblos, Kraków, Tarnów 2002. 


\section{O potrzebie odróżniania racjonalizmu w epistemologii od prądu ideowego ery Oświecenia}

Aby rozjaśnić sens przedrostka „neo-” w obecnej propozycji terminologicznej, zwróćmy uwagę na szersze zagadnienie: jak on funkcjonuje w opowiadaniu dziejów filozofii. Precedensy w jego stosowaniu są liczne i pouczające.

Przez przedrostek „neo-” oprzedzane są fazy niejako wtórne kierunków filozoficznych, gdy po okresie szczytowym miały okres schodzenia w cień. Jednak w jakiś czas potem pojawiają się znów, z większą siłą dzięki swoistej renowacji, dostosowaniu do nowej fazy w dziejach filozofii.

I tak, przedrostek „neo-” poprzedza nazwy: „kantyzm”, „tomizm”, „pozytywizm”, „platonizm”, „pitagoreizm” itd. Jeśli dla jakiegoś kierunku nie przyjęło się mówić o nowej wersji, na którą wskazywałby ów przedrostek, to bądź dlatego, że taka wersja dotąd nie zaistniała, bądź dlatego, że choć zaistniała, fakt ten nie został dostrzeżony w dostatecznie szerokiej skali.

Teza tego opracowania o powstaniu nowej postaci racjonalizmu za sprawą, przede wszystkim, rewolucji naukowej w logice może mieć oponentów z tej racji, że termin "neoracjonalizm” raczej nie funkcjonuje w filozoficznym dyskursie na tematy epistemologiczne i ontologiczne. Pojawił się natomiast w mocno odmiennym kontekście.

Mianowicie, określa się mianem neoracjonalizmu apel Juliena Bendy, znanego francuskiego intelektualisty, o powrót do idei racjonalizmu oświeceniowego. Był on deprecjonowany w XX wieku przez znaczną część europejskich intelektualistów, skłaniających się ku prądom totalitarnym. Benda nazwał to „zdradą klerków".

Solidaryzując się co do treści z tym rozumnym apelem, nie da się jednak nawiązać w obecnym kontekście do przyjętej przez Bendę terminologii. Racjonalizm oświeceniowy nie jest tym samym, co poglądy klasyków racjonalizmu z XVII wieku, a te właśnie mam na uwadze, mówiąc o renowacji racjonalizmu w XX wieku. Tak więc, co innego znaczy „neoracjonalim” jako kontynuacja Oświecenia, a co innego jako kontynuacja, z jednoczesną rewizją, wersji klasycznej. Różnica jest dwojaka.

Racjonalizm oświeceniowy znajduje się w opozycji do irracjonalizmów, takich jak religijny fanatyzm czy zmitologizowane ideologie polityczne. Natomiast klasyczny jest kierunkiem będącym w opozycji do połączonych sił empiryzmu 
(w epistemologii) oraz nominalizmu (w ontologii). Oczywiście, racjonalizm klasyczny jest też przeciwny irracjonalizmowi, ale jest to dalekie od wyczerpania jego bogatej problematyki.

Druga odmienność tkwi w tym, że gdy Benda postuluje rewindykację racjonalizmu z epoki Oświecenia, to nie podejmuje kwestii, czy i jakie zmiany należałoby doń wprowadzić, biorąc pod uwagę nabyte w międzyczasie doświadczenie historyczne czy uwarunkowania nowej epoki. Natomiast neoracjonalizm w przyjętej tu perspektywie postuluje głęboką reformę klasycznego. Prowadzą do niej przełomowe odkrycia $\mathrm{w}$ teorii liczb i w logice, a także nowe prądy w pojmowaniu natury umysłu.

Do zilustrowania sensu „neo-" niech posłużą analogie historyczne. Neotomizm nie jest tomizmem $\mathrm{z}$ czasów scholastyki. Tamten przejął żywcem nauki Arystotelesa, natomiast neotomizm jest próbą uzgodnienia tomizmu tradycyjnego ze współczesnym stanem wiedzy. Z kolei neopozytywizm podziela z pozytywizmem Comte'a postawę antymetafizyczną i empiryzm, ale jedno i drugie w istotny sposób modyfikuje środkami logiki matematycznej (z jej fazy do roku 1931): mianowicie, przybiera na drugie imię termin „empiryzm logiczny”, a metafizykę stara się unicestwić przez logicznq̨ analizę języka.

Matematyka subiektywna a matematyka obiektywna - skąd biorą się postępy tej subiektywnej?

Co istotnie nowego wnosi neoracjonalizm do wcześniejszego racjonalizmu? Najkrótszą odpowiedź zarysowałem na wstępie, w pierwszej sekcji tego artykułu. Nie wystarczy to jednak, żeby ukazać, jak neoracjonalizm daje znacząco nowe względem wersji klasycznej uprawomocnienie intuicji oraz nowe ujęcie stosunku między rolą intuicji i rolą algorytmów w rozwiązywaniu problemów matematycznych, i nie tylko matematycznych ${ }^{10}$.

Aby zdać sprawę $\mathrm{z}$ tej odmienności, pomocne będzie sformułowane przez Gödla rozróżnienie matematyki obiektywnej i subiektywnej:

Matematyka obiektywna jest to system wszystkich prawdziwych sądów matematycznych. Matematyka subiektywna jest to system wszystkich sądów dających się dowieść. Matematykę obiektywną cechuje niewyczerpywalność - inexhaustibility - co znaczy, że wciąż nowe intuicje będą się pojawiać w rozwoju

10 W sprawie pojęcia algorytmu zob.: A.A. Markov, The Theory of Algorithms, Acad. Sci. USSR, Moscow 1954. 
matematyki [in the development of mathematics new intuitions will continue to arise $]^{11}$.

W tych stwierdzeniach Gödla mamy jądro albo, inaczej mówiąc, punkt ciężkości nowoczesnego racjonalizmu. W odróżnieniu od klasycznego racjonalizmu Kartezjusza i Leibniza ten jest infinistyczny (niewyczerpywalność z racji nieskończoności dziedziny) i fallibilistyczny. To drugie znaczy, że w matematyce, podobnie jak w naukach empirycznych, nie ma wyników nieomylnych i ostatecznych, ponieważ intuicje w danej nauce doskonalą się w miarę jej rozwoju. Gödel ilustruje to przykładem intuicji dotyczącej pojęcia obliczalności, które - zrazu niejasne - sprecyzowało się dzięki koncepcji maszyny Turinga.

Powstało na tym gruncie nowe rozumienie kluczowego w racjonalizmie pojęcia rozwiązywalności problemu. Klasykom racjonalizmu wspólne było przeświadczenie, że każdy problem naukowy da się rozumowo rozwiązać choć u Leibniza uzasadnienie tej wiary było $\mathrm{z}$ gruntu inne niż u Kartezjusza. Ten drugi wierzył w nieograniczoną moc, niezawodność i uniwersalność obmyślonej przezeń metody polegającej na ciągach minimalnych kroków dedukcji, z których każdy był aktem niezawodnej intuicji.

Leibniz natomiast wierzył w moc, niezawodność i uniwersalność metody algorytmicznej, którą projektował jako procedurę dającą się stworzyć na gruncie - również pozostającego $\mathrm{w}$ fazie projektu - uniwersalnego, czysto formalnego języka nauki. W niecałe trzy wieki później heroldem takiego programu algorytmizacji był David Hilbert.

Hilbert był w sytuacji daleko lepszej niż Leibniz, gdyż powstał w międzyczasie język symboliczny, w którym daje się zapisać każdą myśl matematyczną za pomocą symboli jednoznacznie zdefiniowanych, o kształtach niezawodnie rozpoznawalnych wzrokowo. Język ten jest wyposażony w reguły, które gwarantują, że określone przekształcenia formuł prawdziwych dają w wyniku tylko twierdzenia prawdziwe. Dopiero w takim języku można tworzyć algorytmy dowodzenia. Stworzył go Gottlob Frege i przedstawił studium pod wymownym tytułem: Begriffsschrift, eine der arithmetischen nachgebildete Formelsprache des reinen Denkens (1879).

Zawiera się w tym tytule zarys recepty na uprawianie metamatematyki w sposób algorytmiczny. Język pojęciowy czystej myśli jest to taki język, w którym

11 Cyt. za Ch. Parsons, Philosophy of Mathematics in the Twentieth Century: Selected Essays, Harvard University Press, Cambridge, MA - London, England 2014, s. 100. 
pojęcia definiowane są graficznie: jednemu pojęciu odpowiada jeden zapis symboliczny bez pośrednictwa języka fonetycznego. Dzięki temu możliwe się stają reguły przekształcania formuł biorące pod uwagę tylko kształty ciągów symboli. Takie reguły, jako dotyczące cech czysto fizycznych (kształtu czyli formy symboli), da się ująć w formie algorytmów opisujących wykonywane na tych fizycznych obiektach czynności autora dowodu.

$\mathrm{Na}$ algorytmiczny charakter postępowania zwraca też uwagę część tytułu mówiąca, że jest to język ukształtowany na wzór arytmetycznego. To znaczy takiego, w którym można obliczać wartości funkcji (dodawanie etc.), biorąc pod uwagę jedynie kształt i kolejność symboli, nawet bez rozumienia, do czego się one odnoszą. To może czynić także maszyna, był więc w pomyśle Frego zalążek maszyny Turinga - idealnego rozwiązywacza problemów drogą algorytmiczną.

Wątek ten kontynuował Hilbert, mając na uwadze, że stworzony przez Fregego aksjomatyczny system logiki, składa się z rachunku zdań i rachunku predykatów, i dowodzenie twierdzeń w tym pierwszym podlega algorytmizacji. Na tej podstawie, rozumując niejako przez analogię, żywił Hilbert przekonanie, że do podobnej efektywności da się doprowadzić rachunek predykatów. Wtedy mielibyśmy algorytm, który o każdej formule zapisanej w języku logiki predykatów potrafiłby wykazać, że z danej aksjomatyki (o ile jest niesprzeczna) wynika asercja tej formuły lub jej negacja. Na ten jeden uniwersalny algorytm składałyby się reguły dowodzenia należące do logiki zdań i logiki predykatów.

Podsumujmy tę hipotezę Hilberta krótką formułą, w której posłużymy się zmienną $p$, odnoszącą się do zbioru problemów, i zmienną $a$, odnoszącą się do zbioru algorytmów. Predykat $R$ czytamy w kontekście: algorytm a rozwiązuje problem $p$.

\section{$\mathrm{HH}: \exists a \forall p(a R p)$}

Turing i Church udowodnili, że nie ma takiego uniwersalnego algorytmu dla logiki, to znaczy: są takie formuły, o których żaden istniejący algorytm nie rozstrzygnie, czy dana formuła, czy też jej negacja wynika z aksjomatów logiki. Tak więc słynna maksyma Hilberta, że gdy musimy coś wiedzieć, to kiedyś się o tym dowiemy dzięki posiadanym algorytmom, okazała się w tej postaci nie do utrzymania.

Nie znaczy to jednak, że zawarty w niej optymizm poznawczy i wiara w moc algorytmu nie da się utrzymać, gdy zgodzimy się na postać mniej radykalną. 
Taką propozycję zawierają wypowiedzi Gödla w jego rozmowach z Hao Wangiem, np. gdy powiada, że podziela z Hilbertem jego optymistyczny racjonalizm. Argument na rzecz swego racjonalizmu podsumowuje Gödel powiedzeniem: there are no undecidable questions of number theory for the human mind. I stąd kolejny wniosek, bardzo dla ludzkiego gatunku optymistyczny: The human Mind surpasses all machines ${ }^{12}$.

Aby jednak uniknąć nieporozumień, trzeba pamiętać, że „rozstrzygalność” (decidability) w języku Hilberta i Gödla oznacza uzyskanie dowodu w postaci algorytmicznej, czyli dającej się sprawdzić maszynowo. Temu warunkowi nie odpowiada np. Andrew Wilesa dowód wielkiego twierdzenia Fermata - choć potwierdzony przez najwybitniejszych recenzentów - dopóki nie będzie zapisany algorytmicznie, czyli w języku interpretowalnym przez maszynę, i potwierdzony przez maszynę, której zadanie to zlecimy, albo przez maszynę samodzielnie dowiedziony.

Tak więc Gödlowską wiarę w ludzki rozum trzeba rozumieć następująco. Rozum posiada zdolność intuicyjnego tworzenia nowych pojęć (czyli odkrywania nowych obiektów matematycznych) i doprowadzania do tak precyzyjnego ich rozumienia, że dadzą się one zdefiniować w postaci układu aksjomatów. Gdy zostanie on dołączony do aksjomatyki już istniejącej teorii sformalizowanej, a więc umożliwiającej tworzenie algorytmów, wtedy dadzą się w niej udowodnić nowe prawdy, nieosiągalne w teorii dotychczasowej.

Tak więc pierwotny pogląd Hilberta, że istnieją dzięki logice predykatów gotowe już algorytmy do rozwiązania dowolnego problemu, zastępujemy poglądem, że dla każdego problemu da się znaleźć, po należytym namyśle intuicyjnym, pewien algorytm, który dany problem rozwiąże. Zapiszmy to w skrócie jako hipotezę Gödla:

HG: $\forall p \exists a(a R p)$

Widać, że HG wynika z HH, lecz nie odwrotnie. Tak więc optymizm Gödla jest mniejszy niż Hilberta, gdy idzie o wiarę w aktualnie istniejące algorytmy. Hilbertowskie „będziemy wiedzieć” otrzymuje teraz sens niejako infinitystyczny:

12 Cytaty z Gödla wraz z przekonującym komentarzem podaje m.in. L.M. Pereira w artykule Gödel and Computability zawartym w tomie: Progress in Artificial Intelligence: 13th Portuguese Conference on Artificial Intelligence, ed. by J.M. Neves, M.F. Santos, J.M. Machado, Springer, Berlin 2007. 
wiedziałoby się za sprawą algorytmów wszystko, o ile miałoby się na to nieskończenie wiele czasu.

To ograniczenie naszej, rodzącej się z intuicji, matematyki subiektywnej bierze się, oczywiście, z niewyczerpywalności matematyki obiektywnej, o której mówi wypowiedź wyróżniona powyżej (z racji jej doniosłości dla myśli Gödla) ${ }^{13}$.

\section{Współdziałanie intuicji $\mathrm{z}$ algorytmem w historycznym rozwoju matematyki. Negowanie tego faktu przez doktrynę algorytmizmu}

Jako struktura skończona matematyka subiektywna nigdy nie będzie odwzorowaniem całości matematyki obiektywnej, ale w miarę swego rozwoju odwzorowuje z tego nieskończonego obszaru coraz więcej. A dzieje się to za sprawą procesu, jakim jest współdziałanie intuicji z algorytmem.

Na przykład antyczna matematyka grecka w sensie subiektywnym nie miała pojęciowej reprezentacji obiektu, jakim jest zero, choć istnieje on odwiecznie w dziedzinie matematyki obiektywnej. Matematykom greckim, pomimo ich wyrafinowania, tej akurat intuicji zabrakło. Nauka europejska wzbogaciła się o nią dopiero w średniowieczu, czerpiąc ją z przekazanej przez Arabów matematyki hinduskiej.

Bliższy nam w czasie przypadek to ewolucja logiki do tak zaawansowanej postaci, że mogły się z niej wyłonić teoretyczne podstawy informatyki. Prześledźmy w skrócie ten proces.

Z intuicji językowej i logicznej Arystotelesa zrodziła się sylogistyka. Nie oferowała ona algorytmów, ale dostarczała systematycznej i dokładnej procedury kontrolowania poprawności rozumowań. Takie procedury są niejako w pół drogi między intuicją i algorytmem.

Intuicja Leibniza dopatrzyła się w tej procedurze aspektu algebraicznego. Pomysł jej algebraizacji pozostał u Leibniza w szufladzie. Niezależnie jednak pojawiła się u George Boole’a w połowie XIX wieku, gdy kwitła w Anglii intensywna twórczość algebraików. Na takim gruncie intuicja Boole’a miała sprzyjające

13 Przywołane w tym fragmencie pojęcie intuicji, będące próbą zdania sprawy z myśli Gödla, zdaje się bliskie rozważaniom Stanisława Krajewskiego o fenomenie emergencji z pierwszego rozdziału jego książki Czy matematyka jest nauką humanistyczną?, zatytułowanego Emergencja w matematyce?. Czy taka zbieżność rzeczywiście istnieje, to sprawa, która wydaje się warta dalszej dyskusji. 
warunki i dojrzała do stworzenia przezeń systemu algebraicznego generującego algorytmy rozwiązywania równań.

Ciąg dalszy jest dziełem Fregego, który na gruncie algebry Boole’a stworzył rachunek zdań z jego eleganckimi algorytmami. Gdy był już taki wzorzec rachunku logicznego, nasuwał się pomysł, żeby poszukiwać algorytmów rozwiązywania wszelkich problemów w zakresie całej logiki, łącznie z rachunkiem predykatów (określanym także jako rachunek kwantyfikatorów).

Nie powstałby on zapewne w tym czasie, gdyby nie to, że rozwój matematyki w XIX wieku, w szczególności analizy matematycznej, wymagał częstego stosowania kwantyfikatorów w kontekście zmiennych np. w wyrażeniach typu: „dla każdego $x$ istnieje takie $y$, że ...”. Częste obcowanie z jakimś obiektem prowadzi do coraz lepszego rozumienia jego własności oraz jego relacji do innych obiektów. Rozumienia, czyli intuicji. Im lepiej dany obiekt rozumiemy, tym wierniej i dokładniej potrafimy go opisać, co w postaci najdoskonalszej przybiera formę aksjomatyki. Natomiast od niej, gdy system aksjomatyczny podda się formalizacji, już tylko krok do algorytmów.

Algorytmy z kolei wspierają intuicję. Bez nich byłaby często bezradna. Na przykład, żeby znaleźć dowód twierdzenia Fermata, Andrew Wiles, dając się prowadzić intuicjom, musiał jednak dla ich realizacji wykonywać niezliczone ilości obliczeń, w których stosował algorytmy arytmetyczne. Gdyby arytmetyka nie rozwinęła się do postaci zawierającej potrzebne mu algorytmy, na nic by się zdały intuicje genialnego matematyka.

Niewiele jednak dadzą takie historyczne opowieści, gdy mamy do czynienia z opozycją stanowczego algorytmisty, czyli mechanicysty. Nie może on przyjąć do wiadomości, że w poznawaniu świata, czyli w rozwiązywaniu wszelakich problemów, może być coś, co nie byłoby wykonalne dla kierowanej algorytmem maszyny. Przy takiej postawie Wiles okazuje się maszyną, której rzekome intuicje to są $\mathrm{w}$ gruncie rzeczy procesy kierowane przez zapisane $\mathrm{w}$ ciele Wilesa algorytmy. Streśćmy tezę algorytmizmu w takim oto równaniu:

TA: Umysł = mózg = UMT (uniwersalna maszyna Turinga)

Mózg i umysł to obiekty, z którymi myśl ludzka ma do czynienia od wieków, a filozofowie od dawna pytają, jaka zachodzi między nimi relacja. Stosunkowo nowe pojęcie UMT służy algorytmizmowi do tego, żeby sformułować odpowiedź, że jest to identyczność. Jeśliby tak było, to pojęcie intuicji stałoby się 
bezprzedmiotowe. Wtedy każdy dający się rozwiązać problem matematyczny maszyna umiałaby rozwiązać przez wykonanie stosownego programu, czyli algorytmu sformułowanego w „zrozumiałym” dla niej języku.

Skąd jednak biorą się algorytmy w UMT? Wiadomo, że zapisuje je na taśmie (czy innym nośniku) programista. Skąd ma je programista? Mówi się, że to on tworzy programy. Ale jak może je tworzyć, skoro - według algorytmizmu - jego mózg jest maszyną Turinga, zdolną wykonywać tylko, co w niej zaprogramowano?

Kto jednak miałby zaprogramować programistę? Inny ludzki programista? Nazwijmy tę drugą postać słowem „Webb” na cześć Judsona Chambersa Webba, będącego radykalnym zwolennikiem algorytmizmu ${ }^{14}$. Skąd się wziął algorytm zaimplementowany przez Webba w mózgu informatyka wyposażającego w program jakąś UMT? Musiał już istnieć w mózgu Webba. A tam skąd się wziął? Czyżby był niezbędny jakiś Webb nr 2, a dalej nr 3 itd.?

Może na takie pytania algorytmista odpowie słowem „Przyroda”. Przyroda byłaby wtedy obsadzona w tej roli, jaką Augustyn i Kartezjusz przypisywali Bogu. $\mathrm{Z}$ tą jednak różnicą, że w ich rozumieniu Stwórca działał planowo, przyroda zaś - wedle Darwina - losowo, przez przypadkowe mutacje.

Jeśli algorytmista nie zaakceptuje tego argumentu, dajmy spokój dyskusji i spróbujmy nakreślić (w następnej sekcji) scenariusz alternatywny.

\section{Wiedza opisowa a wiedza zadaniowa. Wrodzoność pewnych intuicji u podstaw zadaniowej}

Weźmy za motto naszego scenariusza wypowiedź Turinga z 1939 r.:

Mathematical reasoning may be regarded as the exercise of a combination of two faculties, which may be called intuition and ingenuity. The activity of the intuition consists in making spontaneous judgments which are not the result of conscious trains of reasoning. These judgments are often, but by no means invariably correct ${ }^{15}$.

14 Zob. J.C. Webb, Mechanism, Mentalism, and Metamathematics. An Essay in Finitism, Reidel, Dordrecht 1980.

15 A. Turing, Systems of Logic Based on Ordinals, „Proceedings of the London Mathematical Society” 1939, Vol. 45, s. 161-228. Akcenty kursywą - W.M. 
Zwrot „spontaneous judgements” wyraziście i zdecydowanie odróżnia intuicyjność od mechaniczności algorytmu, nie mającej nic wspólnego ze spontanicznością. Wyróżnienie zaś kursywą zdania końcowego zdecydowanie odróżnia neoracjonalizm od racjonalizmu klasycznego. Nowością jest pogląd zwany fallibilizmem, że intuicja bywa zawodna, a więc wymagająca weryfikacji, podczas gdy Platon i późniejsi klasycy racjonalizmu uważali ją za niezawodną i tym samym nieodwoływalną (infallibilizm). Takiej niezawodności nie przypisuje intuicji ani Turing, ani Gödel, z czego się bierze w ich racjonalizmie rys fallibilistyczny.

Co się tyczy niezawodności intuicji, trzeba mieć na uwadze, że jest to cecha stopniowalna. Istnieje pewien poziom podstawowy, gdzie funkcjonują elementarne intuicje wrodzone, którym przysługuje najwyższy stopień niezawodności. Są to swego rodzaju pewniki. Natomiast gdy intuicje w toku budowania teorii skłaniają nas do jakichś hipotez, to mają charakter raczej pomysłów niż pewników i wymagają sprawdzania.

Pogląd, że istnieje jakaś wiedza wrodzona, zwany natywizmem, bywa przez niektórych zaliczany do przeżytków staroświeckiego racjonalizmu. A jednak wbudowuje się on siłą rzeczy w neoracjonalizm, jeśli zastanowić się dokładniej, na czym polega wiedza.

Mamy szeroko przyjęte odróżnienie wiedzy opisowej, wyrażanej zwrotem „wiem, że jest tak a tak”, od wiedzy zadaniowej wyrażanej zwrotem „wiem, jak wykonać takie a takie zadanie”. Kto się zaznajomił z twórczością Gilberta Ryle'a $^{16}$, odczuwa jako swojskie i bezdyskusyjne operowanie zwrotami „knowing that” (wiedza opisowa) i "knowing how” (wiedza zadaniowa).

Nie podejmując na razie kwestii wiedzy opisowej, zgódźmy się, że istnieje bogaty repertuar wrodzonej wiedzy zadaniowej, m.in. w postaci instynktów. Nikt nie uczył małego ssaka, jak ssać pierś matki, a on to wie od chwili urodzenia. Oczywiście, ten rodzaj instynktów, najprymitywniejszy, nie doprowadzi do intuicji służących poznawaniu świata i ciągłemu tej wiedzy rozszerzaniu. Są jednak inne, dopełniające o nowe elementy.

Zwróćmy uwagę na to, jak powstają u zwierzęcia odruchy warunkowe. Do ich zaistnienia konieczna jest pewna wrodzona zdolność zasługująca na określenie: instynkt abstrakcji. Pies, którego uderzono kijem koloru białego, np. z gałęzi brzozy, będzie też uciekał od kija innej barwy, np. brązowej. Pomija więc (co jest

16 Zob. G. Ryle, The Concept of Mind, Barnes \& Noble, New York 1949; wydanie polskie: tenże, Czym jest umysł?, tłum. W. Marciszewski, PWN, Warszawa 1970. 
istotą abstrakcji) cechę nieistotną z punktu widzenia zagrożenia bólem, a koncentruje się na istotnej, którą jest kształt i zapewne wielkość, porównywalna z tą, której doświadczył przy pierwszym spotkaniu z kijem w ręku człowieka.

Przeanalizujmy scenariusz bardziej wyrafinowany: abstrakcji połączonej $\mathrm{z}$ wnioskowaniem według logicznej reguły odrywania. Będzie to historia kota, który nauczył się otwierać drzwi zamknięte na klamkę, poświadczona przez wiarogodnych obserwatorów.

Nim opanował tę sztukę, kot przyglądał się ludziom, którzy otwierali drzwi naciśnięciem klamki od góry i pociągnięciem drzwi do siebie. Przy jego nikłej posturze było to nie do naśladowania, ale osiągnął skutek na swój sposób. Musiał skupić uwagę na fakcie pochylania się klamki w dół i abstrahować od tego, czy dzieje się to $\mathrm{w}$ wyniku nacisku od góry czy pociągnięcia od dołu. To drugie było w jego mocy poprzez skok i zawieszenie się przednimi łapami na klamce, podczas gdy tylne posłużyły do odepchnięcia się od ramy drzwi, które uchylały się wtedy na tyle, żeby kot mógł wymknąć się na dwór.

Abstrakcji wymagała też operacja odciągnięcia drzwi od ramy. Trzeba było pominąć różnicę między ruchem dostępnym dla człowieka i ruchem dostępnym dla kota i wyabstrahować wspólny jednemu i drugiemu skutek. Ponadto mózg kota musiał dostrzec zależność między przyczyną (akcja ludzka lub kocia) a skutkiem, co my ludzie opisujemy zdaniem warunkowym. Uznając je za prawdziwe, kot musiał stworzyć fakt będący warunkiem wystarczającym skutku, co jest jak akt uznania za prawdę poprzednika. Miał więc miejsce proces przypominający wnioskowanie według logicznej reguły odrywania.

Takie wnioskowania przeprowadza zwierzę na każdym kroku, gdy rozpoznawszy zależność między przyczyną i skutkiem stara się stworzyć fakt zdolny być przyczyną. Zając, gdy wie, że aby nie zostać pożartym, musi szybko uciekać, podejmuje ucieczkę. Realizuje więc następnik zdania warunkowego, które mówi, jak ocalenie zależy od szybkiej ucieczki.

Nietrudno też odczytać z zachowań zwierzęcia, kiedy postępuje według reguły transpozycji, kiedy według reguły opuszczania alternatywy itp. Dlaczego nie miałoby tak być, jeśli się zgodzimy, że mózg kota czy psa ma takie same bramki boole’owskie, jakie mają mózgi ludzi i komputery? 


\section{Przekształcenia wiedzy zadaniowej w opisową i dziedziczenie intuicji tej pierwszej przez drugą}

Czy warto poświęcać tak wiele uwagi na domniemywanie się logiki w zachowaniach zwierząt? Warto, rzuca to bowiem światło na kontrowersję, w której racjonalizm przypisuje pewnym elementom wiedzy wrodzoność (teza natywizmu) oraz aprioryczność, podczas gdy radykalny empiryzm jednemu i drugiemu zaprzecza.

Wróćmy do odróżnienia wiedzy zadaniowej i opisowej. Omawiane wyżej przypadki zachowań zwierzęcych reprezentują wiedzę zadaniową. Z takiej samej korzysta nieustannie człowiek w bardzo różnorodnych sytuacjach. Oto zbieg mający pogoń za sobą dobiega do rozwidlenia dróg i zauważa, że na drodze po lewej też pojawiła się już pogoń, a nie ma jej po prawej, skręca więc w prawo. Postępuje zatem według reguły opuszczania alternatywy: mam do wyboru lewo lub prawo, droga na lewo skutkowałaby pojmaniem, więc ponieważ nie chcę być schwytany, wybieram kierunek na prawo. Mamy tu rozumowanie, którego szkieletem logicznym jest następująca reguła:

\section{Reg-A: $\quad p \vee q, p \rightarrow r, \neg$ r, a zatem $q$}

Uznać, że ktoś postępuje według tej reguły, to znaczy przypisać mu dysponowanie pewnym elementem wiedzy zadaniowej. Musi to być wiedza wrodzona, gdy jej nabycie nie wymaga instruktażu czy tresury ani wcześniejszych samodzielnych obserwacji. Ktokolwiek by zaprzeczał takiej wrodzoności, musiałby umieć opisać przebieg prowadzącego do niej instruktażu lub treść domniemanych obserwacji.

Widać na tym i podobnych przykładach, jak się przekształca pewien element wiedzy zadaniowej (tutaj A) w przyporządkowany mu jednoznacznie element z pewnego obszaru wiedzy opisowej. Od strony gramatycznej będzie to przekształcenie warunkowego zdania rozkazującego w zdanie warunkowe oznajmujące. Rozważmy rozkazujące będące w swej treści jakąś wskazówką czy dobrą radą.

A. Jeśli masz za sobą pogoń od tyłu i na lewym odgałęzieniu trasy ucieczki, a nie ma jej w prawym odgałęzieniu, to wybierz jako zadanie ucieczkę w prawo. 
Trafność takiej wskazówki z zakresu wiedzy zadaniowej bierze się z prawdziwości sądu oznajmującego, a więc należącego do wiedzy opisowej. Byłby to sąd następujący.

$\mathrm{A}^{*}$. Jeśli uciekinier ma pogoń za sobą, a trasa ucieczki w pewnym punkcie rozgałęzia się na lewo i prawo i na lewym pojawia się też pogoń, to szansę na udanie się ucieczki daje tylko skręt w prawo.

Wyrażenie $A^{*}$ jest zdaniem warunkowym o pewnej probabilistycznej zależności zdarzeń, należy zatem niewątpliwie do wiedzy opisowej. Schematem więc tego zdania nie będzie logiczna reguła wnioskowania, lecz prawo logiki:

$$
\text { Prawo-A*: }((p \vee q) \wedge(p \rightarrow r) \wedge \neg r) \rightarrow q
$$

Takie transformacje reguł w prawa i praw $\mathrm{w}$ reguły są dla logika chlebem powszednim. Nie będzie więc traktował wiedzy zadaniowej i wiedzy opisowej jako nie mogących przenikać się wzajem obszarów.

Jeśli przyjąć, że pewne elementy wiedzy zadaniowej, jak te z powyższego przykładu, w trywialny sposób dają się przekształcać w odpowiednie elementy wiedzy opisowej, to czy mamy powód, żeby odmawiać statusu aprioryczności tym drugim? Osobiście nie widzę takiego powodu. Moja empatia dla ściganego przez psy zająca, czyli wczucie się w jego proces myślenia, skłania do poglądu, że dysponuje on wiedzą opisową $\mathrm{w}$ postaci Prawa- $A^{\star}$ (czemu by nie, jeśli ma w mózgu bramki logiczne?). Ale taka „empatia” nie jest argumentem w dyskusji naukowej. Może być co najwyżej zagajeniem dyskusji, i z tą intencją zgłaszam pod dyskusję moją hipotezę co do niektórych elementów wiedzy apriorycznej ludzi i zwierząt.

\section{O tym, jak intuicja wspomaga procedury algorytmiczne i jak dzieje się to $\mathrm{z}$ wzajemnością}

Wnikając $\mathrm{w}$ biologiczne podstawy poznania intuicyjnego, odeszliśmy od postawionego na wstępie problemu uprawomocnienia intuicji intelektualnej, w szczególności matematycznej. Przypomnijmy, że od Platona po wiek XVII legitymizowało ją przekonanie o kontakcie umysłu z jakimś czynnikiem poza-przyrodniczym, któremu zawdzięczałby umysł wiedzę o przedmiotach idealnych, czyli abstrakcyjnych, jak powszechniki czy abstrakty matematyczne. 
Racjonalizm nowoczesny nie podtrzymuje owej legitymizacji. Jednocześnie ma do czynienia $\mathrm{z}$ rewolucją naukową w logice i matematyce, która z jednej strony ujawnia, nie przewidywane wcześniej, ograniczenia możliwości poznawczych, gdy idzie o rozwiązywanie problemów algorytmiczne, a z drugiej - wskazuje sposoby minimalizowania tych ograniczeń dzięki interwencji aktów intuicji.

Otwiera to nową problematykę. Jak myślenie intuicyjne w nowym rozumieniu, podbudowanym przez rozważania przyrodnicze, ma się do rozwiązywania problemów w postępowaniu algorytmicznym?

Wyprawa w świat zwierząt i odnalezienie w nim zdolności myślenia logicznego, które funkcjonuje na poziomie instynktów lub odruchów warunkowych, prowadzi do zauważenia pewnej kategorii wrodzonych sądów a priori. Należąc do poziomu wiedzy zadaniowej, mogą one niekiedy przekształcać się w sądy z zakresu wiedzy opisowej. Przez to te drugie również się lokują w sferze wiedzy apriorycznej i wrodzonej.

Intuicja w perspektywie neoracjonalizmu jest stopniowalna co do jasności i pewności. Najbliższe tym cechom są intuicje pierwotne, których część powstaje z przekształcenia wiedzy zadaniowej w opisową. Intuicje z tego poziomu, który jest najniżej w sensie znajdowania się w punkcie wyjścia, służą jako środki kontrolowania intuicji z bardziej zaawansowanych poziomów wiedzy. Im dalej bowiem od punktu wyjścia, tym większe jest ryzyko pojawienia się niejasności pojęć czy pomyłek w rozumowaniu.

Stosunkowo jasne i pewne są np. prawa wnioskowania w rachunku zdań czy aksjomaty arytmetyki Peana, ale nie da się tego powiedzieć o całokształcie teorii mnogości, gdzie kontrowersje wokół pewnika wyboru czy hipotezy continuum świadczą o niedomaganiach naszych intuicji.

Przekonującym przykładem dochodzenia do większej jasności i pewności przez oparcie się na teoriach, które cieszą się tymi atrybutami w stosunkowo dużym stopniu, może być arytmetyzacja analizy matematycznej, dokonująca się na przestrzeni XIX wieku. Niejasne zrazu i kontrowersyjne pojęcia z będącej dziełem Leibniza fazy początkowej klarowały się w miarę ich formułowania w terminach arytmetyki (prace Weierstrassa) i zapisywania ich z pomocą kwantyfikatorów ${ }^{17}$.

Gdy tak się rzeczy mają, to w budowaniu gmachu nauki ważne jest znalezienie intuicji najbardziej podstawowych - pewnych, jasnych i wyraźnych, w myśl

17 A. Grzegorczyk, Zarys logiki matematycznej, PWN, Warszawa 1969, s. 483. 
ideału nakreślonego przez Kartezjusza. To one mają być mocnym fundamentem gmachu.

Zastanawiał się nad tym Gödel w rozmowach z Hao Wangiem i wymienił przykładowo dwie kandydatury: logiczną regułę odrywania (modus ponens) i arytmetyczną zasadę indukcji. Pójdźmy za pierwszą z tych sugestii, drugą zostawiając do dyskusji matematykom, w których pracy jest indukcja chlebem powszednim.

Co się tyczy reguły odrywania, stosować ją umieją odruchowo nie tylko małe dzieci, lecz także zwierzęta, jak kot z poprzedniej sekcji. A oto inny przypadek: psa, który indukcyjnie doszedł do ogólnego zdania warunkowego (implikacji), że zawsze, gdy sięgam po smycz, to następuje wyjście na spacer. Gdy to widzi, nie posiada się z radości, co świadczy, że na podstawie asercji implikacji oraz poprzednika dochodzi do asercji następnika. Taki przypadek wiedzy zadaniowej podpada pod schemat odrywania, z uszczegółowieniem do konkretnej sytuacji, co oddamy wprowadzając w miejsce zmiennej $x$ stałą indywiduową, np. $a$.

Odr-konkr: $(\forall x(P(x) \rightarrow Q(x)) \wedge P(a)) \rightarrow Q(a)$.

Skąd wiemy, że formuła Odr-konkr jest prawdziwa? Nie informuje o tym żaden ze zmysłów, nie wyprowadzamy jej też z jakiejś aksjomatyki. Pozostaje się zgodzić, że poznajemy tę zależność intuicyjnie jako wrodzoną prawdę a priori; potwierdzają to zachowania opisanych wyżej kota i psa.

Jaki ma $\mathrm{z}$ tego pożytek postępowanie algorytmiczne? Weźmy jako przykład logiczne algorytmy dowodzenia twierdzeń. Posługują się one regułą odrywania jako podstawowym środkiem dowodowym (nie dotyczy to algorytmów w post-gentzenowskich systemach bez reguły cięcia, jak tabele semantyczne Betha ${ }^{18}$ itp.). Nie miałoby się ich do dyspozycji, gdyby Frege nie sprecyzował formalnie w swym Begriffsschrift pojęcia implikacji, na którym się wspiera reguła odrywania ${ }^{19}$.

Tak intuicja prowadzi do algorytmów. Z drugiej strony, algorytmy są niezbędne do wspomagania intuicji. Banalnym przykładem jest fakt, że $\mathrm{w}$ intuicyjnie prowadzonym dowodzie arytmetycznym trzeba coś mnożyć, potęgować, pierwiastkować itd., do czego służą algorytmy takich działań.

18 Por. E.W. Beth, Aspects of Modern Logic, Reidel, Dordrecht 1970.

19 G. Frege, Begriffsschrift, eine der arithmetischen nachgebildete Formelsprache des reinen Denkens, Halle a. S. 1879. 


\section{Pewnik abstrakcji - koronny przykład intuicji w wiedzy zadaniowej i wiedzy opisowej}

Jako drugą ważną kandydaturę na reprezentanta intuicji wrodzonych prawd apriorycznych zgłaszam teoriomnogościowy pewnik abstrakcji (pewnik komprehensji), w skrócie PA, w jego pierwotnej „naiwnej” formie; ta wystarczy do naszych celów (postać wyrafinowana to aksjomat wyróżniania z ZF, broniący przed antynomiami, które jednak nie grożą w obecnym temacie).

PA: $\exists z \forall x(x \in z \leftrightarrow \varphi(x))$

Aby zanalizować ów charakter aprioryczny PA i jego doniosłość poznawczą, skorzystajmy ze zwięzłej charakterystyki natywizmu podanej w książce Rebera.

In its contemporary form nativism has come to represent those orientations that stress the genetic, inherited influences on behavior and thought over the acquired, experiential influences. The most vigorously defended contemporary form of nativism is, of course, that articulated by Noam Chomsky ${ }^{20}$.

Chomsky twierdzi, że nabywanie języka nie jest możliwe bez wrodzonej $\mathrm{w}$ tym kierunku zdolności, którą nazywa language competence. Kluczowym elementem kompetencji językowej jest rozpoznawanie struktur składniowych, w szczególności zdaniowych.

Do tej tezy Chomsky'ego trzeba dołączyć drugą, że nie mniej kluczowe jest posługiwanie się pewnikiem abstrakcji od najwcześniejszej fazy przyswajania sobie przez dziecko pierwszego języka, który nazywamy „ojczystym”. Innych można się uczyć za pomocą słownika podającego przekłady ze znanego już języka na nieznany, ale nie jest to możliwe, gdy nie zna się jeszcze żadnego języka.

Pewnik abstrakcji jako część kompetencji językowej nie musi, oczywiście, a we wczesnym stadium nie może, należeć do wiedzy opisowej, jak ta wyrażona formułą PA. Jest to wiedza nieświadoma (tacit knowledge), ale realnie działająca na rzecz zadania, jakim jest przyswajanie sobie predykatów, czyli wyrażeń obejmujących jakąś klasę; nazywamy ją zakresem danego wyrażenia - rzeczownika, przymiotnika, czasownika itd.

20 A.S. Reber, Implicit Learning and Tacit Knowledge: An Essay on the Cognitive Unconscious, Oxford University Press, Oxford 1996, s. 147. 
Dziecko, po raz pierwszy widząc rower, koloru np. niebieskiego, na pytanie „co to?” dostaje odpowiedź „rower”. Gdy zobaczy inny egzemplarz roweru, umie go rozpoznać pod tą nazwą, także gdy jest innego koloru, innej wielkości itd. Jest to klasyczny akt abstrahowania od pewnych jakości, których się dziecko domyśla jako nieistotnych dla bycia rowerem. Gdy mały człowiek dorośnie, a los tak nim pokieruje, że będzie studiował teorię mnogości, to bez trudu podłoży pod formułę PA wspomnienie uczenia się nazwy „rower”: istnieje taki zbiór, że należy doń każdy przedmiot mający takie cechy, jak widziany kiedyś po raz pierwszy egzemplarz roweru (w PA reprezentuje je zmienna „ $\varphi$ ”).

W takich procedurach nauki języka, zwanych ostensywnymi, jawi się wyraźnie natura władzy poznawczej zwanej intuicją. Każdy z nas ma intuicyjną znajomość pewnika abstrakcji, a jest to znajomość wrodzona i wyprzedzająca wiedzę pochodzącą od zmysłów. Ta wiedza aprioryczna może występować jako nieświadoma, bez artykulacji słownej, lub artykułowana w języku, jak formuła PA.

$\mathrm{Na}$ koniec podnieśmy fakt fundamentalny dla charakterystyki intuicji matematycznej. Mianowicie ten, że wśród wyrażeń, których nie da się wprowadzić do języka inaczej niż ostensywnie, znajdują się liczebniki dotyczące małych liczb. Takich, których znajomością dzieci się chwalą, mówiąc „umiem liczyć już do pięciu”, „a ja do dziesięciu”. Da się w tym pierwotnym poznawaniu liczebników iść na tyle daleko, na ile da się ogarnąć - co do liczby elementów - pole widzenia.

Tak zdobywamy najbardziej pierwotną, sprzężoną ze zmysłami intuicję liczb naturalnych. Będziemy się wspinać na wyższy poziom abstrakcji, gdy nauczymy się, również ostensywnie, stosunku następstwa liczb, a potem przez iterowanie następnika i kolejne akty abstrakcji będziemy docierać do liczb dowolnie wielkich. Przykładem takiej przygody może być wspinaczka po nieskończonej drabinie Russella teorii typów.

Ta fascynująca opowieść o postępach myśli ku nieskończoności powinna się znaleźć w obecnym opracowaniu jako wtajemniczenie w najwyższe osiągnięcia intuicji matematycznej. Przekroczyłoby to jednak dopuszczalne dla obecnej publikacji ramy edytorskie. A co ważniejsze, lojalność wobec Czytelnika wymaga, żeby raczej zalecić najwyborniejsze w tym względzie opracowania specjalistów aniżeli proponować jakąś wtórną wobec ich dzieł popularyzację.

Jako głębokie i aktualne studium warto mieć na uwadze tekst Solomona Fefermana Turing's Oracle: From Absolute to Relative Computability and Back ${ }^{21}$.

${ }^{21}$ S. Feferman, Turing's Oracle: From Absolute to Relative computability and Back, w: The Once and 
Studium to wyjawia sekret, jak intuicja matematyczna, metaforycznie zwana przez Turinga „wyrocznią" (oracle), zdolna jest przezwyciężać ograniczenia procedur algorytmicznych odkryte przez Gödla i przez samego Turinga, a zarazem uzyskiwać nowe, coraz efektywniejsze algorytmy, żeby wspomagały kolejne kroki intuicji.

Nie są to bowiem ograniczenia absolutne. Są relatywne względem określonego systemu pojęć wyrażanych w stosownej aksjomatyce. A po coraz mocniejsze aksjomaty jest $\mathrm{w}$ stanie sięgać geniusz matematyczny. Świadczy o tym historia matematyki. Nie mniej w tym względzie przekonująca jest refleksja Gödla, Turinga czy Churcha. Zwłaszcza gdy jest rozwijana tak po mistrzowsku, jak czyni to Feferman w cytowanym wyżej studium. Sekundują temu inni autorzy, którzy opublikowali swoje prace w tym samym tomie zbiorowym co Feferman, a który nosi wiele mówiący tytuł: The Once and Future Turing: Computing the World.

I tak, dzięki wizjom Gödla, Turinga i rzeszy innych logików istnieje szansa, aby nasze intuicje intelektualne były wyrażane coraz precyzyjniej i przybliżały się się do postaci algorytmicznej. A im dokładniej, aż po granice algorytmu, wyrażamy myśli, tym większy jest ich potencjał owocowania nowymi intuicjami, które będą prowadzić do nowych algorytmów, i tak na przemian, w tym twórczym cyklu, w jakim się dokonuje postęp wiedzy.

\section{Post scriptum}

Powyższy tekst został poddany krytycznej dyskusji przez Recenzentów, którzy prócz propozycji natury technicznej zgłosili pewne uwagi polemiczne. Nadesłane przez nich teksty obejmuję tu nazwą „recenzja” w liczbie pojedynczej.

Tworząc nową wersję, odniosłem się w szczególności do dwóch uwag. Jedna $\mathrm{z}$ nich dotyczy relacji między matematyką subiektywną i obiektywną $\mathrm{w}$ rozumieniu Gödla. Dla jej wyeksponowania umieściłem odpowiedni tekst w ramce. Spotkał się on z dość szeroko rozpisanym zastrzeżeniem Recenzenta. Uznałem, że optymalną strategią dyskusyjną będzie: miast bronić trafności mojej parafrazy, zastąpić ją tekstem bliższym dosłownemu sformułowaniu samego Gödla, oraz odesłać Dyskutanta do Parsonsa (zob. powyżej wyróżniony cytat), autora będą-

Future Turing: Computing the World, eds. B. Cooper, A. Hodges, Cambridge University Press, Cambridge 2016. 
cego wybitnym znawcą myśli Gödla, który opatruje słowa Gödla bardzo instruktywnym komentarzem. Ta modyfikacja pociągnęła dość znaczne uzupełnienia i zmiany w tekście następującym po tym cytacie.

Druga uwaga krytyczna to kwestionowanie mojej tezy, że zdolność rozumowania przysługuje także zwierzętom. Oponent ma zapewne na myśli to, że zwierzęta nie układają wyrażanych słowami sylogizmów. To oczywiste, że nie. Dlaczego jednak werbalizację miałoby się uważać za coś w rozumowaniu koniecznego? Najbardziej efektywne są rozumowania bezsłowne, w których nie traci się czasu i energii na poszukiwanie słów, lecz operuje się bezpośrednio np. na obrazach, najczęściej wzrokowych, a znaczna część tej pracy dokonuje się w podświadomości.

Gdy Napoleon pod piramidami skutecznie poderwał do walki żołnierzy okrzykiem „czterdzieści wieków patrzy na was”, to nie miał czasu ani potrzeby zajmować uwagi przesłankami dla konkluzji: „takimi słowami da się poderwać wojsko do walki”. Nie doszłoby do tak skutecznego aktu, gdyby Napoleon nie miał odpowiednich przesłanek w swojej mózgowej „bazie danych”. Musiał w tym celu wiedzieć, jaką wiedzą historyczną muszą dysponować francuscy żołnierze, żeby zrozumieć intencję wodza. Trzeba też było, żeby zdawał sobie sprawę, jak na takie słowa zareaguje żołnierskie poczucie honoru. Musiał się tym przesłankami kierować, bo bez tego nie osiągnąłby zamierzonego efektu. Ale wcale nie musiał ich mieć w polu świadomości.

Tak jest na każdym kroku. Na przykład z okrzykiem Wilhelma Zdobywcy, który zdecydował o zwycięstwie pod Hastings. Albo z inteligentną szybką ripostą, która rozkłada na łopatki oponenta. W takich przypadkach o błyskawiczności riposty decyduje ekonomiczność biorąca się z bez-słowności i bez-świadomości (co do przesłanek rozumowania i co do jego formy logicznej).

Warto też w tej kwestii mieć na uwadze fakt, że zdążył się już utrwalić termin automated reasoning, jako nazwa procesu wykonywanego przez automat. Skoro tak, to nawet przy pojmowaniu zwierząt tak deprecjonującym ich naturę jak u Kartezjusza (zalicza je on do automatów) da się o nich z sensem powiedzieć, że rozumują, i czynią to $\mathrm{z}$ reguły poprawnie od strony formalnej.

Poświęcam tak wiele uwagi rozumowaniu zwierząt, ponieważ wiele takich rozumowań zdaje się możliwymi do opisu i wyjaśnienia w kategoriach zachowań instynktownych. Odruchy warunkowe to rodzaj uogólnień. Te zaś w przypadku generalizacji czynionych $\mathrm{w}$ nauce opierają się na pewniku abstrakcji (kompre- 
hensji). Nie podejrzewamy psa o to, że studiował Cantora czy Fregego, ale do rozpatrzenia jest hipoteza, że biologiczne korzenie tej idei teoriomnogościowej tkwią w jakichś danych instynktownych z kategorii wiedzy zadaniowej.

Co się tyczy urządzeń elektronicznych, jak np. smartfon, to ich inteligentne zachowanie tłumaczy się tym, że $\mathrm{z}$ woli konstruktora działają według praw logiki. Czemu zatem nie przypisać im zdolności logicznego rozumowania? Można i tak, jeśli zechcemy tak dalece rozszerzyć definicję rozumowania.

Stracimy wtedy jednak z pola widzenia ważną różnicę, od której abstrahować nie należy, jeśli chcemy mieć praktyczną, pomocną w naszych działaniach klasyfikację zbioru urządzeń działających wedle praw logiki. Zasadnicza różnica między smartfonem i psem jest taka, że ten pierwszy jest narzędziem człowieka niemającym własnej podmiotowości (jeśli ktoś powie, że psa też używa się jako narzędzia, to zastąpmy go wilkiem). Pies natomiast ma podmiotowość, bo ma swe własne interesy, a chcąc go podporządkować naszym, trzeba go umiejętnie umotywować. Nie ma sensu spór o słowa. Jeśli dla klasy zachowań sterowanych prawami logiki ktoś zdefiniuje osobne nazwy na jej podzbiory, jakimi są ludzie, zwierzęta i roboty, nie będzie to powód do jakiejkolwiek kontrowersji.

\section{Bibliografia}

Bartoś T., Hypermodernizm, czyli co zrobić, by tworzenie nowych pojęć nie poszerzało naszej wiedzy, „Edukacja Filozoficzna” 2018, nr 66, s. 185-201.

Beth E.W., Aspects of Modern Logic, Reidel, Dordrecht 1970.

Boolos G., Logic, Logic, and Logic, Harvard University Press, Cambridge, MA 1999.

Copeland B.J., Shagrir O., Turing versus Gödel on Computablity and the Mind, w: Computability: Turing, Gödel, Church, and Beyond, ed. by B.J. Copeland, C.J. Posy, O. Shagrir, MIT Press, Cambridge, MA 2013.

Feferman, S., Are There Absolutely Unsolvable Problems? Gödel's Dichotomy, „Philosophia Mathematica Advance Access” 2006, Vol. 14, Issue 2, s. 134-152. Feferman S., From Absolute to Relative computability and Back, w: The Once and Future Turing: Computing the World, eds. B. Cooper, A. Hodges, Cambridge University Press, Cambridge 2016. 
Frege G., Begriffsschrift, eine der arithmetischen nachgebildete Formelsprache des reinen Denkens, Halle a. S. 1879.

Gödel K., Über formal unentscheidbare Sätze der Principia mathematica und verwandter Systeme I, „Monatshefte für Mathematik und Physik” 1931, no. 38, s. 173-198.

Gödel, K., Some basic theorems on the foundations of mathematics and their implications - odczyt cytowany jako „Gibbs Lecture”, wygłoszony w 1951, opublikowany w Collected Works, Vol. III: Unpublished Essays and Lectures, ed. S. Feferman et al., Oxford University Press, Oxford 1995.

Grzegorczyk A., Zarys logiki matematycznej, PWN, Warszawa 1969.

Gurevich Y., Platonism, Constructivism, and Computer Proofs vs. Proofs by Hand, w: Current Trends in Theoretical Computer Science. Entering the 21st Century, eds. M. Nielsen, G. Paun, G. Rozenberg, A. Salomaa, World Scientific, Washington, D.C. 2001.

Krajewski S., Czy matematyka jest nauka humanistyczną?, Copernicus Center Press, Kraków 2011.

Marciszewski W., Logic from a Rhetorical Point of View, de Gruyter, Berlin 1994.

Marciszewski W., Murawski R., Mechanization of Reasoning in a Historical Perspective, Rodopi, Amsterdam 1995.

Marciszewski W., Does Science Progress towards Ever Higher Solvability through Feedbacks between Insights and Routines?, „Studia Semiotyczne” 2018, t. XXXII, nr 2, s. 153-185.

Marciszewski W., The progress of science from a computational point of view: the drive towards ever higher solvability, „Foundations of Computing and Decision Sciences" 2019, Vol. 44, Issue 1, s. 11-26.

Markov A.A., The Theory of Algorithms, Acad. Sci. USSR, Moscow 1954.

Parsons Ch., Philosophy of Mathematics in the Twentieth Century: Selected Essays, Harvard University Press, Cambridge, MA - London, England 2014.

Pogonowski J., Kilka uwag o intuicji matematycznej, „Filozofia Nauki” 2012, nr 2(78), s. 107-114.

Progress in Artificial Intelligence: 13th Portuguese Conference on Artificial Intelligence, ed. by J.M. Neves, M.F. Santos, J.M. Machado, Springer, Berlin 2007.

Reber A.S., Implicit Learning and Tacit Knowledge: An Essay on the Cognitive Unconscious, Oxford University Press, Oxford 1996. 
Rodych V., Are Platonism and Pragmatism Compatible?, w: Mistakes of Reason: Essays in Honour of John Woods, ed. J.H. Woods, University of Toronto Press, Toronto 2005.

Ryle G., The Concept of Mind, Barnes \& Noble, New York 1949. Tłum. tenże, Czym jest umyst?, tłum. W. Marciszewski, PWN, Warszawa 1970.

Tieszen R., Gödel and Quine on Meaning and Mathematics, w: Between Logic and Intuition. Essays in Honor of Charles Parsons, eds. G. Sherman, R. Tieszen, Cambridge University Press, Cambridge 2000.

Turing A., On Computable Numbers, with an Application to the Entscheidungsproblem, „Proceedings of the London Mathematical Society” 1937, Vol. s2-42, Issue 1, s. 230-265.

Turing A., Systems of Logic Based on Ordinals, „Proceedings of the London Mathematical Society" 1939, Vol. 45, s. 161-228.

Webb J.C., Mechanism, Mentalism, and Metamathematics. An Essay in Finitism, Reidel, Dordrecht 1980.

Winograd T., Frame representations and the declarative-procedural controversy, $\mathrm{w}$ : Representation and Understanding, eds. D. Bobrow, A. Collins, Academic Press, New York 1975.

Wójtowicz K., Platonizm matematyczny. Studium filozofii matematyki Kurta Gödla, OBI, Biblos, Kraków, Tarnów 2002.

\section{Streszczenie}

Nowoczesny racjonalizm, w skrócie: neoracjonalizm, jest prądem, w którym mieszczą się m.in. Frege, Russell, Church, Bernays, Gödel (najwyraziściej), Quine, Putnam, Kreisel, Chaitin. Przypisuje on istnienie abstraktom, a umysłowi zdolność ich poznawania w sposób intuicyjny. W przypadku obiektów matematycznych, jak uzyskiwane w wyniku abstrakcji zbiory, liczby, algorytmy etc., mówimy o intuicji matematycznej; na niej koncentruje się artykuł. Nazwa „nowoczesny” uwydatnia różnicę w stosunku do racjonalizmu klasycznego z XVII w. Polega to na poniechaniu tezy o doskonałej wiarogodności intuicji matematycznej. Neoracjonalizm opowiada się w kwestii intuicji za fallibilizmem oraz stopniowaniem wiarogodności: tym wyższy jej stopień, im mocniej jest ugrunto- 
wana we wrodzonym wyposażeniu biologicznym (co oznacza natywizm w stylu Chomsky’ego) i w doświadczeniu zmysłowym. Ze względu na fallibilizm, pewne zbliżenie do empiryzmu i odniesienie do biologii, mylące jest nazywanie tego prądu „platonizmem”, stąd propozycja nazwy „neoracjonalizm”.

Słowa kluczowe: abstrakcja, algorytm, doświadczenie, fallibilizm, intuicja, matematyka, neoracjonalizm, platonizm

\section{Summary}

\section{Mathematical intuition as approached by modern rationalism}

Modern rationalism, abbr. neorationalism, is a philosophical orientation to include Frege, Russell, Church, Bernays, Gödel (most distinctly), Quine, Putnam, Kreisel, Chaitin, etc. It claims the existence of abstract entities as classes, numbers, algorithms etc., and mind's ability to intuitively learn about them. When meaning mathematical entities, we speak of mathematical intuition, being in focus of this paper. The adjective "modern" highlights the difference in relation to the classical rationalism of the 17-th century. The modern one denies the mathematical intuition to possess a perfect reliability, and sees it as a gradable faculty which does not enjoy an assured infallibility. The degree of reliability depends on how close is intuition to an inborn biological equipment (what means nativism in Chomsky's style), and to sensory experiences. What is called neorationalism in this paper happens to be called mathematical platonism by other authors. However, on account of fallibilism, a certain tilt toward empiricism, and a significant reference to biology, "Platonism" (as lacking these traits) proves to be less fitting term than is "neorationalism".

Key words: abstraction, algorithm, experience, fallibilism, intuition, mathematics, neorationalism, Platonism 